\title{
A review of direct torque control development in various multilevel inverter applications
}

\author{
Siti Azura A. Tarusan', Auzani Jidin², Mohd Luqman M. Jamil ${ }^{3}$, Kasrul Abdul Karim ${ }^{4}$, Tole Sutikno \\ ${ }^{1,2,3,4}$ Faculty of Electrical Engineering, Universiti Teknikal Malaysia Melaka (UTeM), Malaysia \\ ${ }_{1,2}$ Power Electronics and Drives Research Group, CeRIA, UTeM, Malaysia \\ ${ }^{3,4}$ Electrical Machine Design, Power Electronics and Drives Research Group, CeRIA, UTeM, Malaysia \\ ${ }^{5}$ Department of Electrical Engeenering, Universitas Ahmad Dahlan, Yogyakarta, Indonesia \\ ${ }^{5}$ Embedded System and Power Electronics Research Group (ESPERG), Yogyakarta, Indonesia
}

\begin{tabular}{l} 
Article Info \\
\hline Article history: \\
Received Apr 17, 2020 \\
Revised Jul 22, 2020 \\
Accepted Aug 3, 2020 \\
\hline Keywords: \\
AC drives \\
Direct torque control \\
Multilevel inverter \\
Switching states \\
Voltage vectors
\end{tabular}

\begin{abstract}
Multilevel inverter (MLI) is commonly utilized in direct torque control (DTC) for medium and high-power applications. The additional voltage vectors generated by MLI can be manipulated to achieve the optimal selection for the inverter switching states in the DTC control systems. Previously, a review of DTC which focused more on the two-level inverter for AC machine as well as a review of multilevel converter in industrial applications had been implemented individually. However, a review on DTC development in MLI was insufficient in both papers. Therefore, this paper aims to give a comprehensive review of the improvement of DTC via various MLI applications. It is reviewed according to the applicable multilevel inverter topologies in the DTC system. The comparison of DTC by using conventional and multilevel inverter is synthesized. Thus, this review paper will hopefully lead researchers in further research activities actively.
\end{abstract}

This is an open access article under the CC BY-SA license.

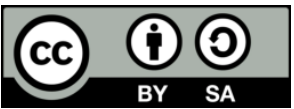

\section{Corresponding Author:}

Siti Azura Binti Ahmad Tarusan

Faculty of Electrical Engineering

Universiti Teknikal Malaysia Melaka

76100 Durian Tunggal, Melaka, Malaysia

Email: sitiazura@utem.edu.my

\section{INTRODUCTION}

Direct torque control (DTC) scheme introduced by Takahashi and Noguchi in 1896 [1] has employed two-level or voltage source inverter (VSI) circuit on its prior application with the aim to control the torque and flux performance by using the appropriate voltage vector. It gains attention in industrial application when the AC machine is the employed in this control scheme. Thus, it gains a lot of attractions from many researchers for implementing the several development of DTC [2]-[7]. Therefore, several review papers, [8], [9] have been published but they are more emphasized to the development on the prior or conventional DTC application.

Meanwhile, multilevel inverter (MLI) is widely applied in the industrial application due to some attributes such as high voltage capability, reduced current harmonic and switching voltage stress the like [10]-[13]. Despite of these advantages, they are interpreted into the review paper that explain the MLI's contribution into industrial application in general [14]-[16]. MLI is also well adapted in DTC due to its abundant voltage vector rather than the limited voltage vector in VSI. Thus, the DTC performance can be more optimized by using the variety control of MLI. However, a review on DTC development adapted by MLI is lack emphasized in the aforementioned review paper. Thus, this paper aims to give a comprehensive 
review of the improvement of DTC via various MLI applications as highlighted in Figure 1. The comparison of DTC by using conventional inverter (VSI) and MLI is synthesized. Thus, it will help lead researchers in to further research activities.

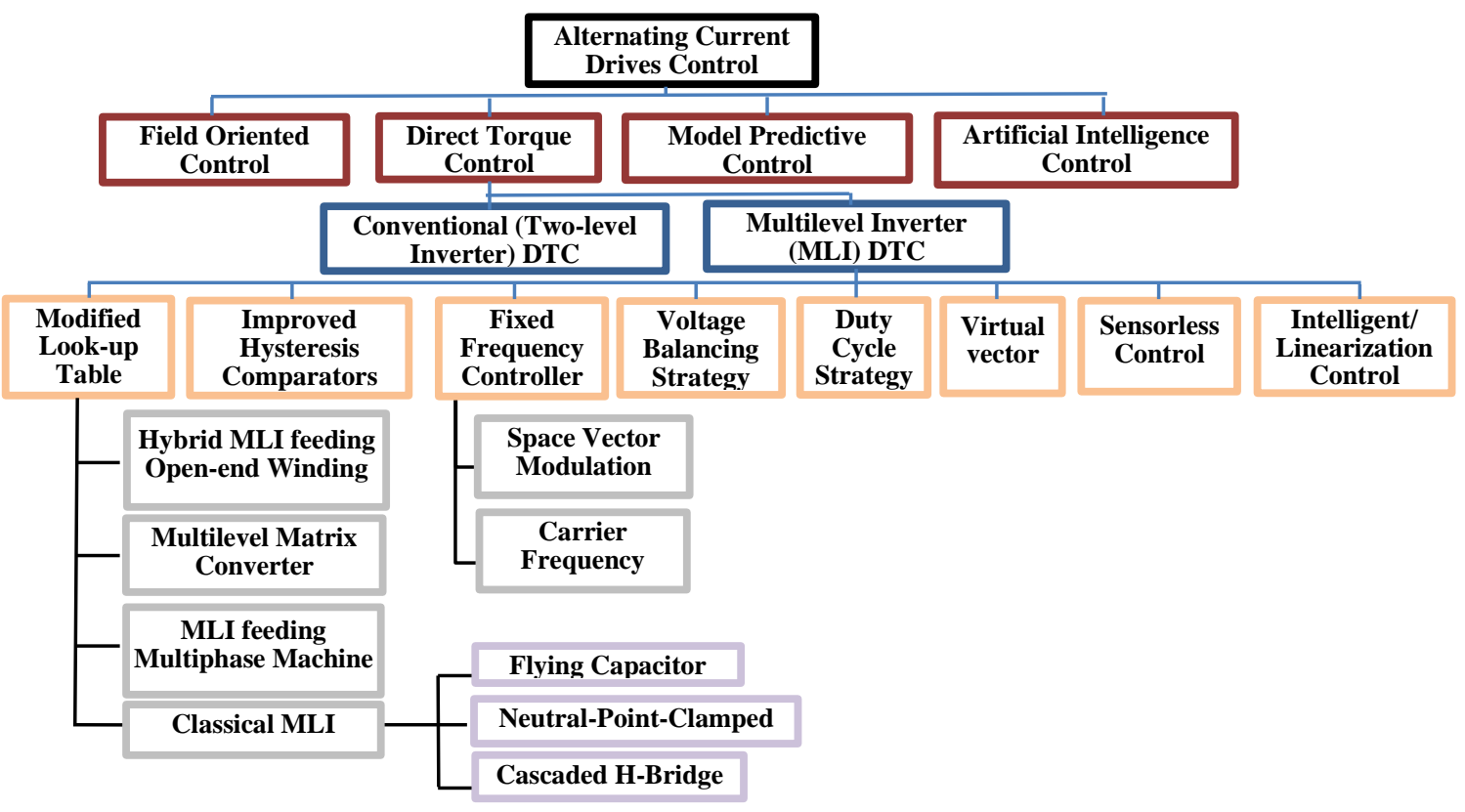

Figure 1. A diagram review of DTC via implemented of MLI

\section{CONVENTIONAL DTC}

The structure of DTC drive control proposed in [1] is illustrated in Figure 2. It consists of torque and flux estimators, a coupled of hysteresis comparators, look-up table and two-level inverter. A pair of control structure as aforementioned obviously controls the two independent variables such as stator flux and electromagnetic torque using two-level and three-level hysteresis comparators. In the previous implementation of DTC, the two-level inverter is employed to drive the AC machine as shown in Figure 3(a). The circuit produces eight voltage vectors which are classified into two zero voltage vectors (V0 and V7) and six active voltage vectors (V1-V6). This is further displayed by the mapping vectors in Figure 3(b). A basis of look-up table DTC is constructed in Table 1 where the voltage vectors are mapped into the sector, the error status of torque ( $\left(\mathrm{Te}_{\text {stat }}\right)$ and stator flux ( $\left(\Psi_{\mathrm{s}_{\text {stat }}}\right)$.

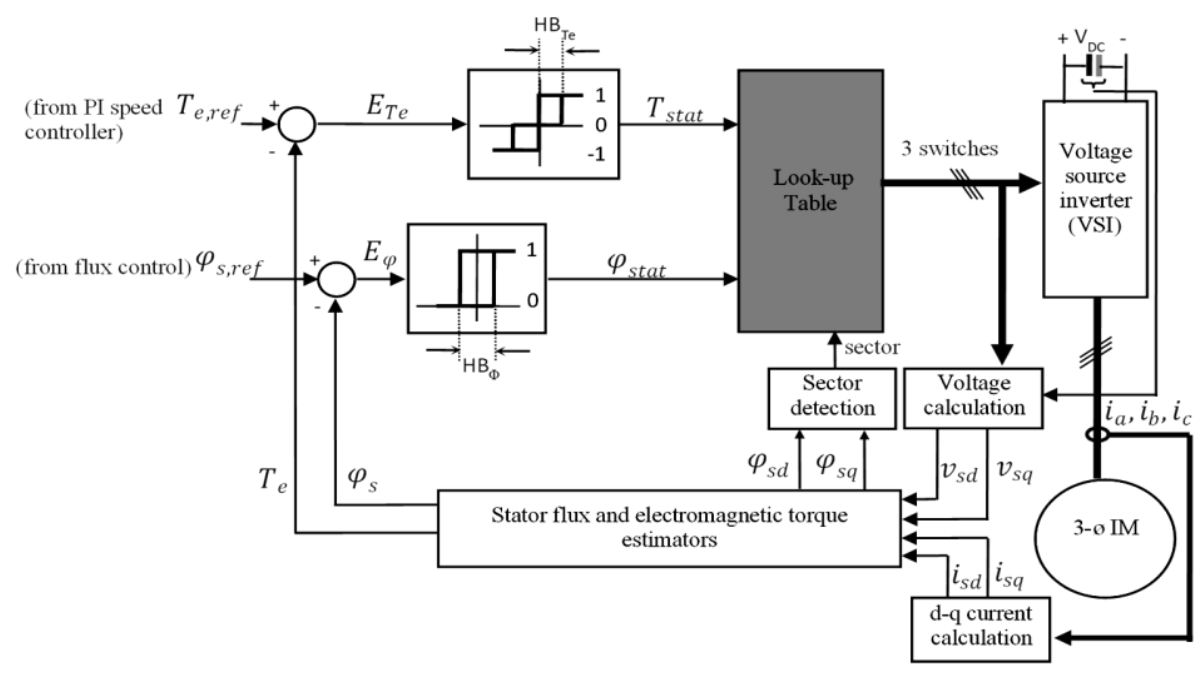

Figure 2. Structure of conventional DTC [1] 


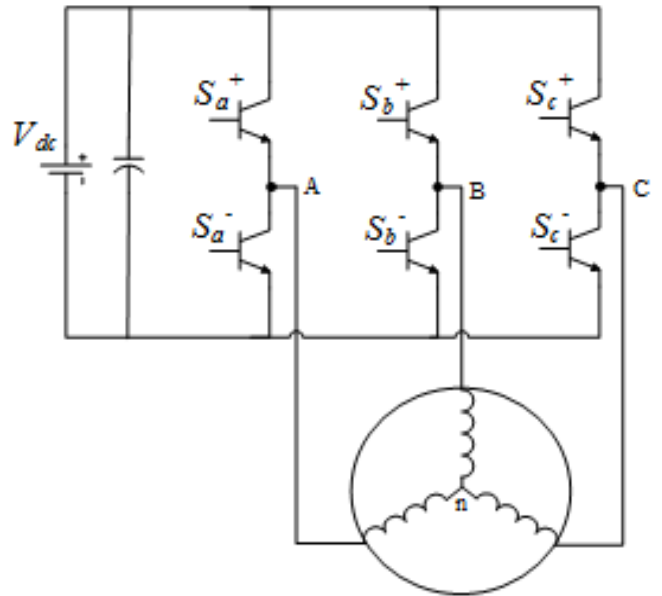

(a)

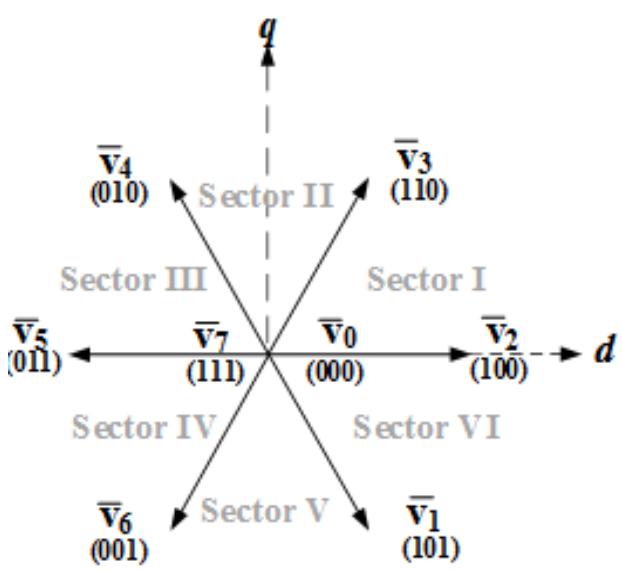

(b)

Figure 3. (a) Two-level inverter circuit and (b) Space vector diagram [1]

Table 1. The look-up table of conventional DTC [1]

\begin{tabular}{|c|c|c|c|c|c|c|c|}
\hline $\begin{array}{l}\mathrm{s} \\
\text { stat }\end{array}$ & $\begin{array}{l}\mathrm{Te} \\
\text { stat }\end{array}$ & $\begin{array}{c}\text { sector } \\
\text { I }\end{array}$ & $\begin{array}{c}\text { sector } \\
\text { II }\end{array}$ & $\begin{array}{l}\text { sector } \\
\text { III }\end{array}$ & $\begin{array}{l}\text { sector } \\
\text { IV }\end{array}$ & $\begin{array}{c}\text { sector } \\
\mathrm{V}\end{array}$ & $\begin{array}{c}\text { sector } \\
\text { VI }\end{array}$ \\
\hline \multirow{3}{*}{1} & 1 & $\begin{array}{c}V_{2} \\
(100)\end{array}$ & $\begin{array}{c}V_{3} \\
(110)\end{array}$ & $\begin{array}{c}V_{4} \\
(010)\end{array}$ & $\begin{array}{c}V_{5} \\
(011)\end{array}$ & $\begin{array}{c}\mathrm{V}_{6} \\
(001)\end{array}$ & $\begin{array}{c}V_{1} \\
(101)\end{array}$ \\
\hline & 0 & $\begin{array}{c}V_{0} \\
(000)\end{array}$ & $\begin{array}{c}V_{7} \\
(111)\end{array}$ & $\begin{array}{c}\mathrm{V}_{0} \\
(000)\end{array}$ & $\begin{array}{c}V_{2} \\
(100)\end{array}$ & $\begin{array}{c}V_{0} \\
(000)\end{array}$ & $\begin{array}{c}V_{2} \\
(100)\end{array}$ \\
\hline & -1 & $\begin{array}{c}V_{6} \\
(001)\end{array}$ & $\begin{array}{c}\mathrm{V}_{1} \\
(101)\end{array}$ & $\begin{array}{c}V_{2} \\
(100)\end{array}$ & $\begin{array}{c}V_{3} \\
(110)\end{array}$ & $\begin{array}{c}V_{4} \\
(010)\end{array}$ & $\begin{array}{c}V_{5} \\
(011)\end{array}$ \\
\hline \multirow{3}{*}{0} & 1 & $\begin{array}{c}V_{3} \\
(110)\end{array}$ & $\begin{array}{c}\mathrm{V}_{4} \\
(010)\end{array}$ & $\begin{array}{c}V_{5} \\
(011)\end{array}$ & $\begin{array}{c}V_{6} \\
(001)\end{array}$ & $\begin{array}{c}\mathrm{V}_{1} \\
(101)\end{array}$ & $\begin{array}{c}V_{2} \\
(100)\end{array}$ \\
\hline & 0 & $\begin{array}{c}\mathrm{V}_{7} \\
(111)\end{array}$ & $\begin{array}{c}V_{0} \\
(000)\end{array}$ & $\begin{array}{c}\mathrm{V}_{7} \\
(111)\end{array}$ & $\begin{array}{c}V_{0} \\
(000)\end{array}$ & $\begin{array}{l}V_{7} \\
\text { (111) }\end{array}$ & $\begin{array}{c}\mathrm{V}_{0} \\
(000)\end{array}$ \\
\hline & -1 & $\begin{array}{c}V_{5} \\
(011)\end{array}$ & $\begin{array}{c}V_{6} \\
(001)\end{array}$ & $\begin{array}{c}\mathrm{V}_{1} \\
(101)\end{array}$ & $\begin{array}{c}V_{2} \\
(100)\end{array}$ & $\begin{array}{c}V_{3} \\
(110)\end{array}$ & $\begin{array}{c}\mathrm{V}_{4} \\
(010) \\
\end{array}$ \\
\hline
\end{tabular}

\section{MULTILEVEL INVERTER DTC}

\subsection{Modified look-up table}

The attributes of conventional DTC are still when applied the MLI except it will increase the voltage vectors. Aside voltage vectors, other variables such as sector, torque and flux error status included in the look-up tables are also susceptible to the traits of MLI. In the classical MLI i.e., flying capacitor (FC), neutral point clamped (NPC), and cascaded H-bridge (CHB) topologies, the voltage vector mapping is enlarged due to the increasing number of levels. Generally, the three- and five-level inverter will generate 64 [17] and 512 [18] voltage vectors respectively. This flexibility encourages the optimal selection of voltage vector from the look-up table [17]-[19]. In FC-DTC, the lookup table was altered as the number of sector was increased into 24 sectors [20]. Meanwhile in NPC-DTC, the modified look-up table based on the optimum current ripple principle and the look-up table with a uniform control method were proposed in [21] and [22] respectively.

Further in the modern topologies of MLI, the hybrid MLI feeding open-end winding (OEW) was introduced in drive application in 1993 [23]. This is done by floating the neutral point of motor winding to connect the dual two-level inverters into both ends of motor windings. Some improvements of its look-up table has been discussed in [24]-[27] related to the extra operation, modified look-up table and improvised switching table. On the other hand, the matrix converter (MC) on DTC was introduced in the early 2000's [28]. Its construction is based on the bidirectional switches performed the sinusoidal input/output current related to the variable input power factor. The study of conventional MC-DTC table can be referred to in [28], [29] followed by its development in [30], [31] through the twelve-sided polygonal structure and sub-region strategy. MLI feeding multiphase machine also brings interest to the drive application that enables employment of the five-phase, six-phase or even higher phases onwards. Further, the research development of five- and six-phase employed in DTC can be referred in [32]-[35] and [36]-[39] correspondingly. 


\subsection{Improved hysteresis comparators}

Hysteresis comparator is a core in the DTC drive. In the classical DTC, the three-level hysteresis comparator yields the error status of torque of $+1,0$ and -1 whilst for the stator flux, the two-level hysteresis comparator yields the flux error status of +1 , and 0 . They still remained in the NPC-DTC [40]. The availability of voltage vectors in MLI tends to increase the level of hysteresis comparators [18], [35]. For instance in [18], the five-level CHB-DTC had proposed eight-level torque and five-level flux comparator using seven and four two-level hysteresis comparator respectively. The eight-level torque hysteresis comparator was denoted by the error status of torque of $+3,+2,+1,+0,-0,-1,-2$ and -3 . Meanwhile, the fivelevel flux hysteresis comparator was denoted by the flux error status of $+2,+1,+0,-0,-1$ and -2 . Typically, the highest value of error status (positive or negative) was recommended for the large voltage vectors to achieve the fast-dynamic torque response. The lowest value (positive or negative) however was recommended for the small or zero voltage vectors to reach the slow torque response as well as minimize the torque ripple [35].

Further analysis regarding the modified hysteresis comparator was discussed in [41] by using threeand five-level CHB-DTC. The three- and five-level CHB have employed the two- and five-level hysteresis comparator respectively. Both levels have applied seven-level hysteresis comparator for torque controller. Figure 4 shows the proposed method of five-level CHB-DTC. This proposed scheme is contributed into the NPC-DTC [42], matrix converter [43] and multiphase machine [39] with the aim of minimizing the steadystate error and torque ripple, as well as harmonic current.

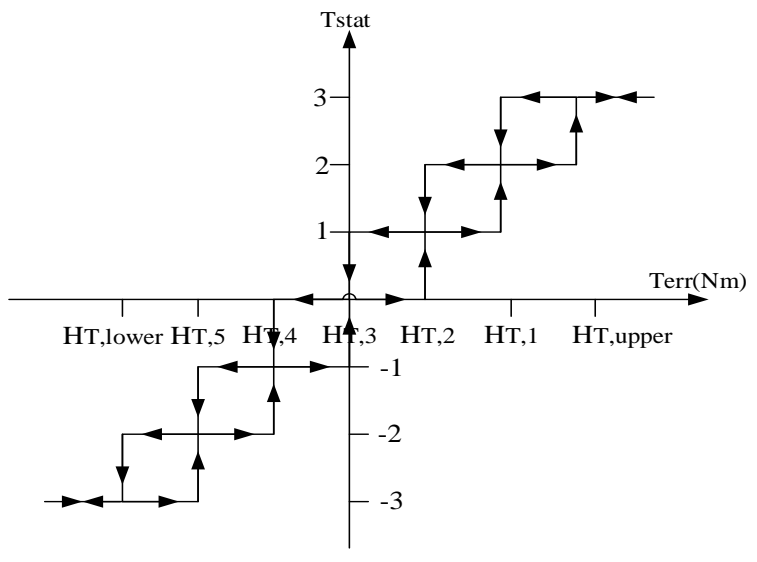

(a)

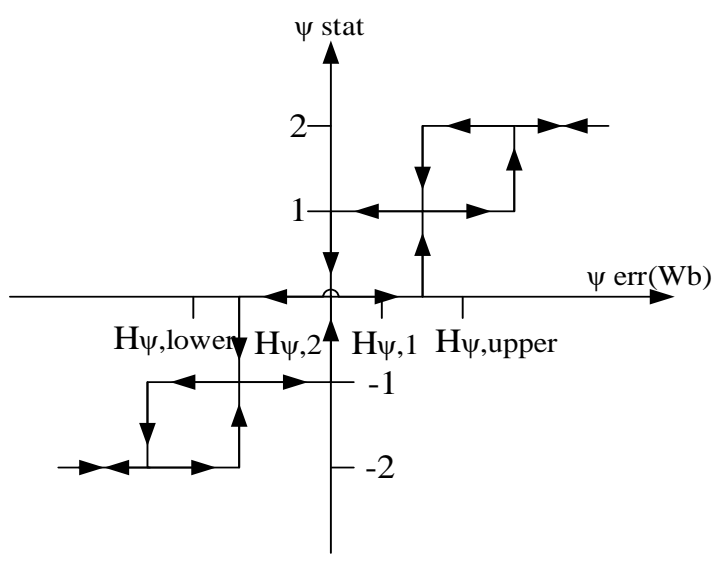

(b)

Figure 4. Hysteresis comparator of (a) 7-level for torque and (b) 5-level for flux in MLI [41]

\subsection{Fixed frequency controller}

The inconsistency of switching frequency in DTC is mainly caused by the torque comparator [44]. Basically, the slope of torque contains several variables such as stator voltage, speed, stator flux and rotor flux. The uncontrollable operating speed may contribute to the unpredictable switching frequency. Thus it is difficult to optimize the DTC performance [9]. Some suggestions have been offered to solve this problem such as Space Vector Modulation (SVM) and carrier frequencies.

SVM was a part of the modulation strategy for DTC in 1992 by Habetler [45]. It controls decouple electromagnetic torque and stator flux by using PI controller to produce the $\mathrm{d}$ - and q-axis voltage. The stator flux angle which is applied in SVM strategy is calculated from the estimated torque and stator flux. Figure 5(a) shows an example of the reference voltage vector $d-q$ which occurs on one of the sectors in the conventional DTC [46]. In the particular sector, the reference voltage vector is located between two adjacent vectors and zero vector with their stipulated time after which the duty cycle is computed to generate the symmetrical switching of SVM.

SVM strategy was extended by using NPC inverter as such in [47], [48]. For example in [48], a new simplification algorithm was constructed for the classical SVM technique. The g-h reference frame or $60^{\circ}$ reference frame that neglected the trigonometric functions to be applied by the classical SVM. Therefore, six triangular sectors were performed by the space vector diagram. However, in MLI, each triangular sector was divided into four small triangular regions as shown in Figure 5(b). Thus, the three vectors nearest to the 
reference vector among the regions were chosen for the SVM computation. By utilizing the g-h reference frame, the reference vector values of $u_{s h}$ and $u_{s g}$ could be determined by several rules declared in [48]. The SVM strategy has been further improved in CHB-DTC [49], hybrid MLI feeding OEW- DTC [50]-[52], MCDTC [53] and the multiphase machine as in [54].

As the substitute of SVM, the fixed or constant switching frequency could be achieved by using triangular waveform or carrier frequency proposed by Idris in 2002 [55], [56]. It replaced the hysteresis comparator of torque controller in DTC and neglected the complicated operation such as SVM. Illustrated in Figure 6(a) is the conventional DTC where the proportional integral (PI) controller regulated the torque error before comparing with the two compliment phases of triangular waveforms which contain the carrier frequencies. This approach was prolonged into MLI as in [3], [57], [58]. As employed in CHB-DTC [57], the constant frequency controller was added with six comparators and six triangular waveforms as shown in Figure 6(b) finally for creating the torque error status.

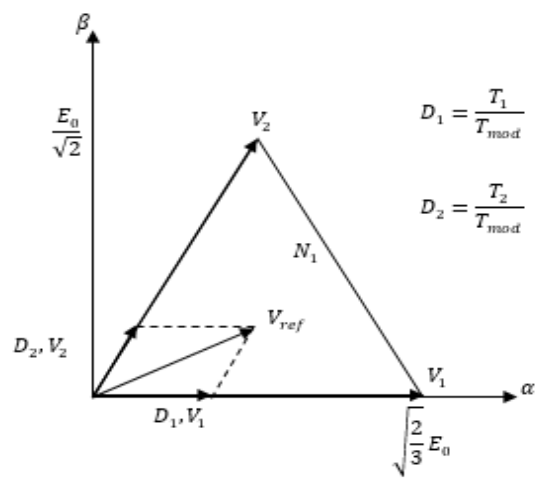

(a)

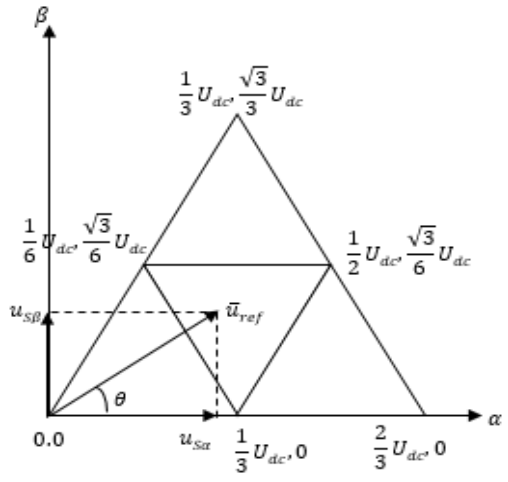

(b)

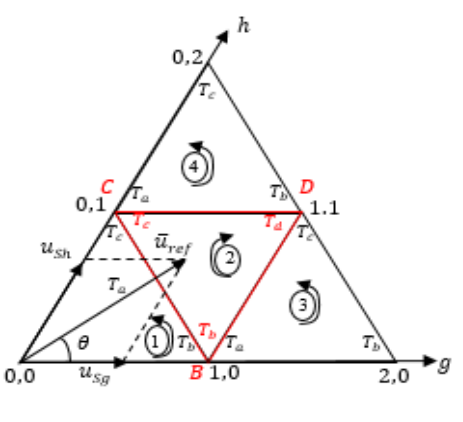

Figure 5. SVM strategy, (a) The reference voltage vector projection on V1 and V2 in sector 1 in conventional DTC [46] and (b) SVM strategy in MLI in sector 1 through four small triangular region coverted from a-b (left) into g-h (right) reference frames [48]

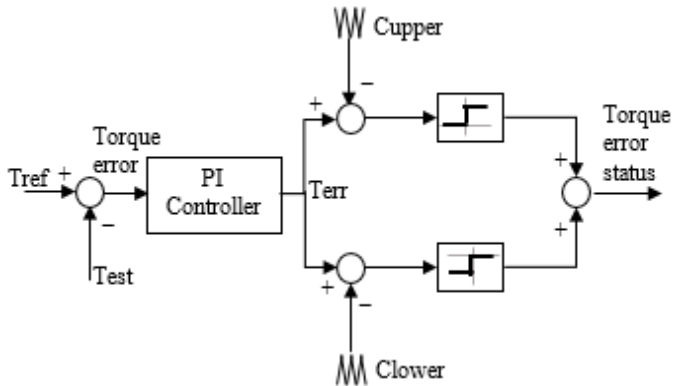

(a)

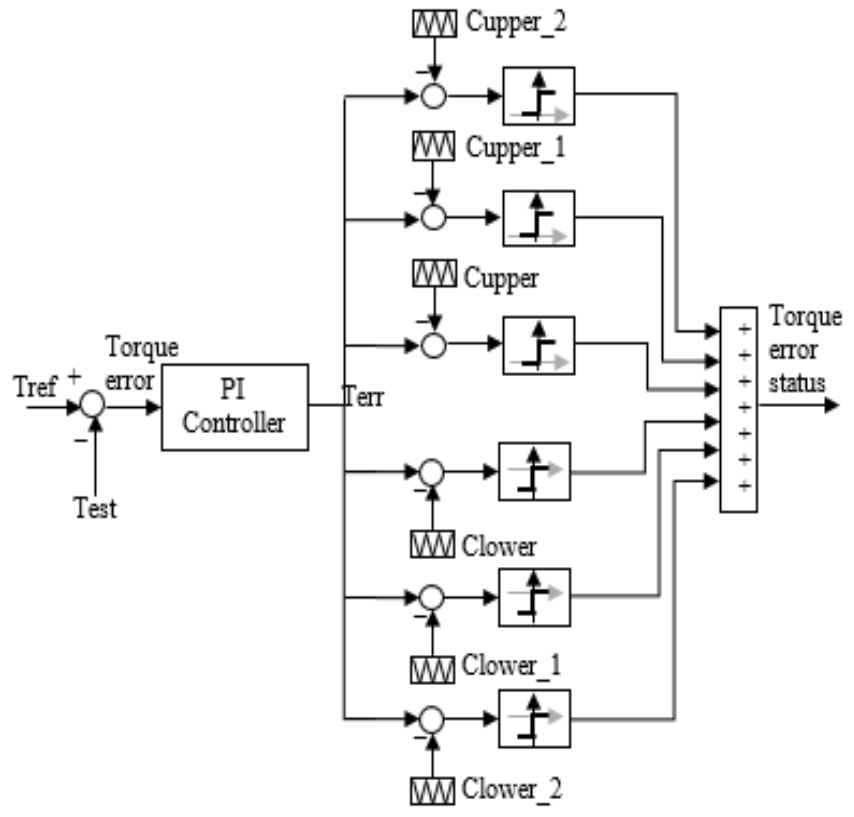

(b)

Figure 6. Carrier frequency controller, (a) conventional DTC [55], [56] and (b) Proposed carrier frequency controller in MLI by [57] 


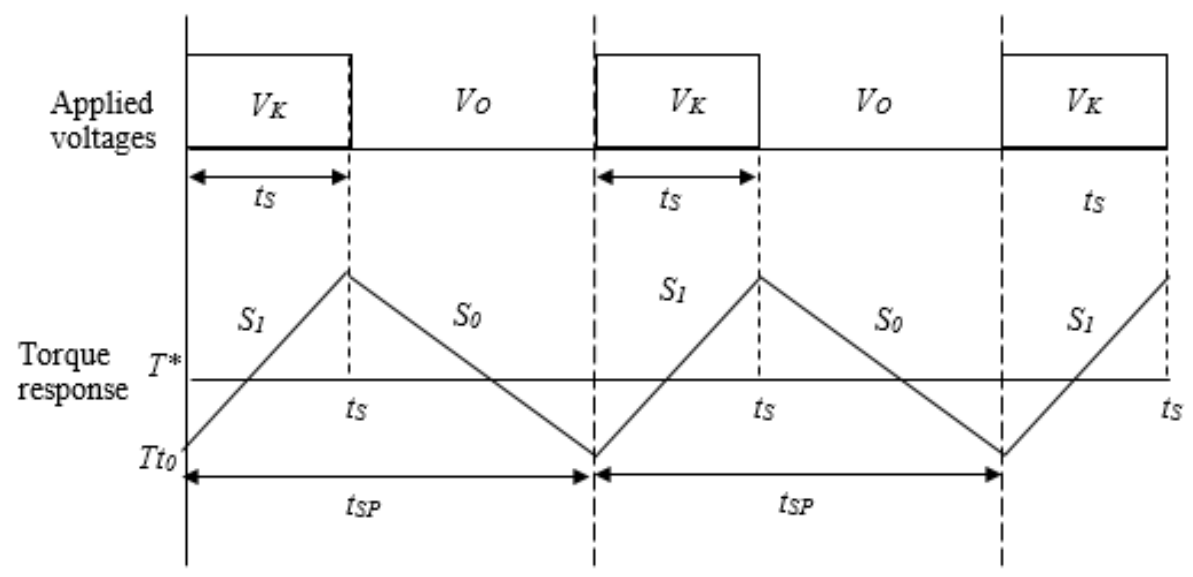

(a)
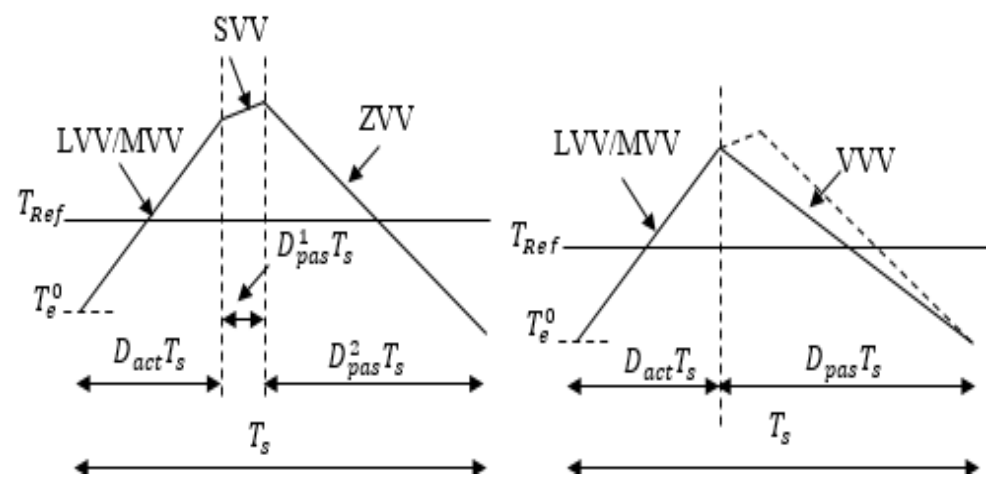

(b)

Figure 7. Duty cycle based strategy, (a) conventional DTC [59] (b) DTC using MLI applying conventional method (left) and modified method (right) by [4]

\subsection{Duty cycle strategy}

Duty cycle based strategy was a typical method for reducing the torque and stator flux ripple in the conventional DTC as introduced by Kang in 1999 [59]. It applied two voltage vectors (one active, $V_{K}$ and one zero voltage vector, $V_{O}$ ) within one interval switching, $t_{S P}$ as shown in Figure 7(a). The duty cycle have been developed by using conventional DTC in [60], [61]. Zero voltage vector and two active voltage vector were employed in [60]. However, it reduced the reliability and capability of DTC. Meanwhile in [61], the three voltage vectors were applied to minimize the torque and stator flux ripple at each switching period. However, the switching losses were increased due to the additional one voltage vector.

In MLI DTC, the duty cycle strategy was developed in [4], [62], [63]. As introduced in [4], the manipulation of voltage vectors within one switching interval was easily determined through the extra voltage vectors. The variety of voltage vectors could be classified into four categories namely (i) large (LVV), (ii) medium (MVV), (iii) small (SVV) and (iv) zero voltage vector (ZVV). In the normal speed operation as illustrated in Figure $7(\mathrm{~b})(\mathrm{left})$, the torque ripple profile was performed using the vector combination of LVV/MVV-SVV-ZVV as proposed in [4]. Due to the complex implementation to compute the duty ratio, the voltage vectors of SVV and ZVV were combined to perform a virtual voltage vector (VVV). As a result, the vector combination of LVV/MVV-VVV was simplified like a normal profile of torque ripple as shown in Figure 7(b)(right). The relationship of torque slope and machine speed was also studied in [4] that encouraged the derivation of the slope equations for particular vectors for such the combination of LVV-VVV, MVV-VVV and SVV-ZVV.

\subsection{Voltage balancing}

The issue of voltage balancing was mainly concerned in NPC-DTC and FC-DTC. This was due to the built-in capacitors which was located parallel to the input DC voltage and switching devices. The 
capacitors are exploited by the fluctuation of DC voltage triggered by the voltage deviation flowing the three phase AC machines or loads. As a result, it may lead to the severe condition on input DC voltage of inverter circuit. Several methods to solve the matters had been suggested by researchers in [4], [64]-[67].

A control algorithm of voltage balancing was proposed in [64] for controlling the signals in the inverter-leg by using the input of required voltage level, capacitor voltage states and current direction. Meanwhile in [4], [65], the extra look-up table was built as a two-level hysteresis comparator was added to control the voltage deviation through the DC link capacitors in the DTC systems. For instance in [65], the proposed method was shown in Figure 8. The voltage balancing method which focused on the line voltage harmonic had resulted in a slight increase of current harmonic compared to the basic condition in [66].

\subsection{Virtual vector}

The virtual vector (VV) principal was first introduced in 2002 by Tan [68] through the three-level NPC inverter. It is a part of synthesized vector that is identical with the conventional SVM except it has a fixed position. In [68], a modified look-up table was performed by comprising of 12 virtual vectors and zero vectors in low-speed region. This concept was improved in [69] by solving the large fluctuation of neutral point voltage and eliminating the voltage shifting on the previous NPC-DTC.

Multiphase machine had also applied the VV concept [33], [39]. For synthesizing the VV, two methods are explained in [33]; 1) the volt-second balance technique and, 2) flux angle in the x-y plane. Most of the researchers preferred to employ the volt-second balance technique to remove the flux in $x-y$ plane. By using the volt--second balance technique, the synthesized of large VV was produced by merging the voltage vector 6 (large vector) and 15 (medium vector). Meanwhile the small VV was produced by merging the voltage vector 22 (small vector) and 15 (medium vector). Consequently, the synthesized of VV large $\left(\mathrm{V}_{11}\right.$ $\left.\mathrm{V}_{20}\right)$ and small $\left(\mathrm{V}_{1}-\mathrm{V}_{10}\right)$ voltage vectors were constructed as illustrated in Figure 9.

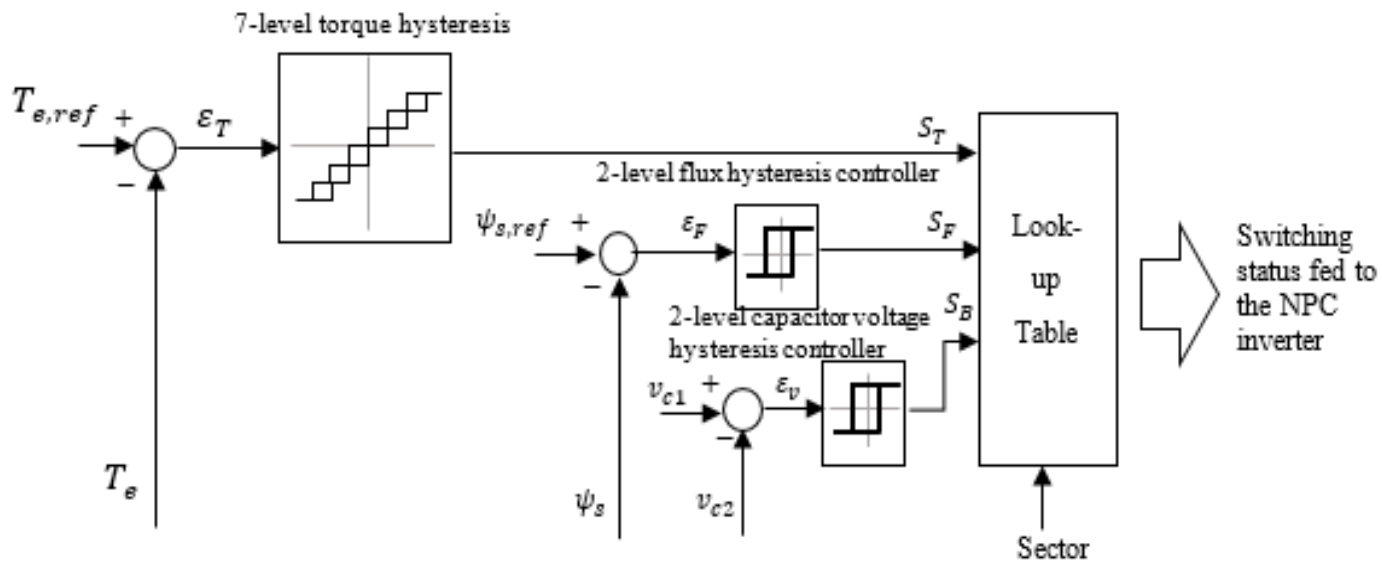

Figure 8. Voltage balancing strategy in NPC-DTC [65]

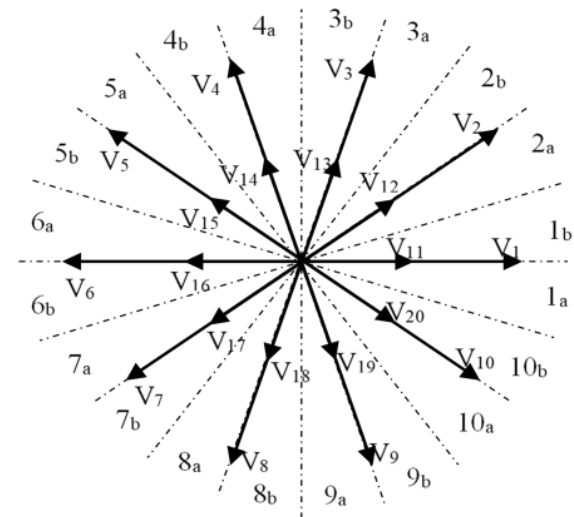

Figure 9. Virtual vector of five-phase machine [33] 


\subsection{Sensorless control}

Normally in the DTC application, the knowledge of rotor speed was ignored in the implementation the flux stator estimation. This is due to the availability of sampled values from the stator voltages and current as described by Monti in 1998 [70]. The stator voltage model employed in flux stator estimator produced the drawback at low-speed regions caused by the small magnitude of induced rotor voltages and currents. It was due to the stator flux failure to regulate at very low frequency and the existence of integration operation. Hence, numerous solutions had been suggested such as full-order observer, adaptive scheme, extended Kalman Filter the like [70], [71]. Nevertheless, this problem remained unsolved in MLI.

Generally, the adaptive observer was often utilized because of the abandonment of open-loop integration and the insertion of available mechanism in the stator resistance estimation [72]. An example of the sensorless DTC using speed adaptive flux observer was shown in Figure 10 by using NPC-DTC. In [73], the combination of flux observer and speed observer was employed in the MC-DTC. Elsewehere, another sensorless method called as a parameter strategy was proposed by Lee [74]. By assuming a constant rotor speed, a parameter estimation was produced by the conversion of state estimation when applied the error model. The Lyapunov analysis was utilized to test the stability properties of the estimator. As a result, a good response against the parameter variation was achieved using the proposed method.

Other sensorless methods recommended for multiphase machine-DTC were proposed in [75], [76]. The sensorless control using power measurement was suggested in [75] which involved the calculation of active and reactive power (PQ), and also the variable of arbitrary reference frame multiscalar $(\mathrm{x}, \mathrm{y})$. The sensorless method through the combination of flux linkage observer and Extended Kalman Filter (EKF) was presented in [76]. Although the aforementioned method required more calculations and high computational power, but it may achieve the better position and speed estimations due to the high noise-rejection ability.

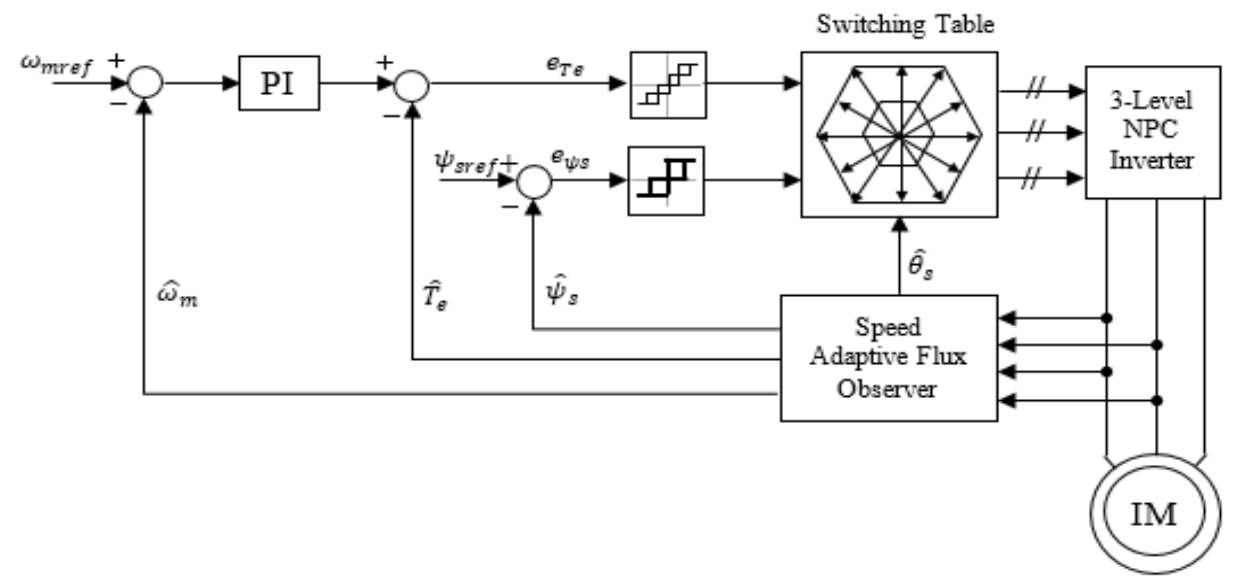

(a)

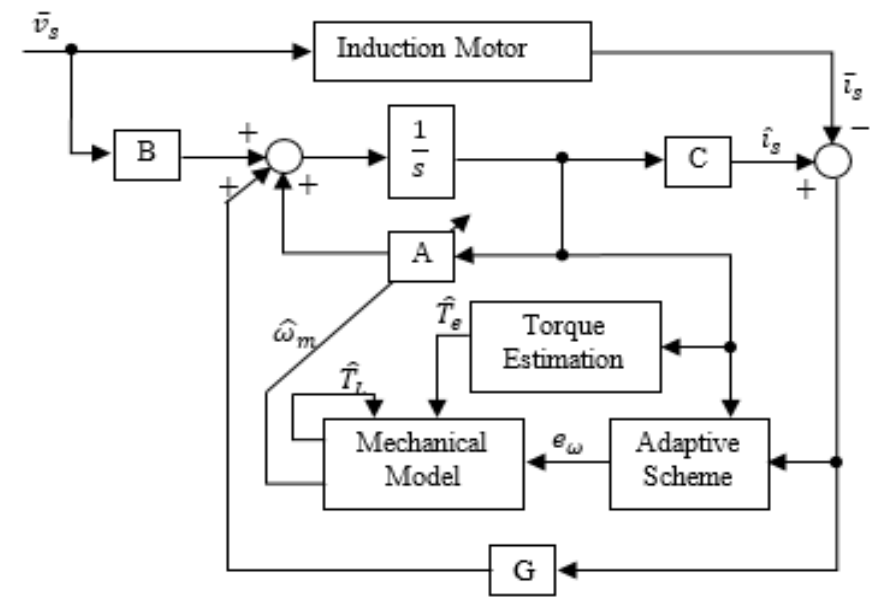

(b)

Figure 10. Sensorless DTC using speed adaptive flux observer, (a) Block diagram of sensorless NPC-DTC and (b) Structure of speed adaptive flux observer [72] 


\subsection{Intelligent/digital control}

The artificial intelligence (AI) control such as fuzzy, neural network, generic algorithm and the like applied the advanced and modern algorithm to solve the drawback of DTC. Fuzzy logic as the basic intelligent control was proposed by Bird in 1997 [77]. It has still been employed in conventional DTC recently [78]. In the MLI, this control strategy was extended as suggested in [47], [79], [80] whereby it replaced the hysteresis comparators to control either speed, stator flux or electromagnetic torque. The structure of fuzzy logic controller by using CHB-DTC is illustrated in Figure 11 [79]. Elsewhere, the fuzzy logic was adapted in MC-DTC [80].

Neural network (NN) based on neurons concept contributes well in conventional DTC [81], [82]. Meanwhile in MLI, several developments of neural network are done [83]-[86] such as nine sub-nets that contained 12 layers and 134 neurons in MC-DTC [83], four- subnetwork in NPC-DTC [84] and three neurons of hidden layer in five-phase machine DTC [85]. Besides, the radial-basis function network (RBFN) in MC [87] is applied to achieve a simple structure of control algorithm and neglect the limit condition on the design constant as the purpose of stability. Another control strategy called as feedback linearization (FBL) technique fed on DTC was suggested in CHB [88]. The aim of this strategy was to convert the nonlinear system into the linear system by involving some of the algebraically transformation. On the other hand, the combination of DTC control and non-linear control was also developed in multiphase named as backstepping control in [89].

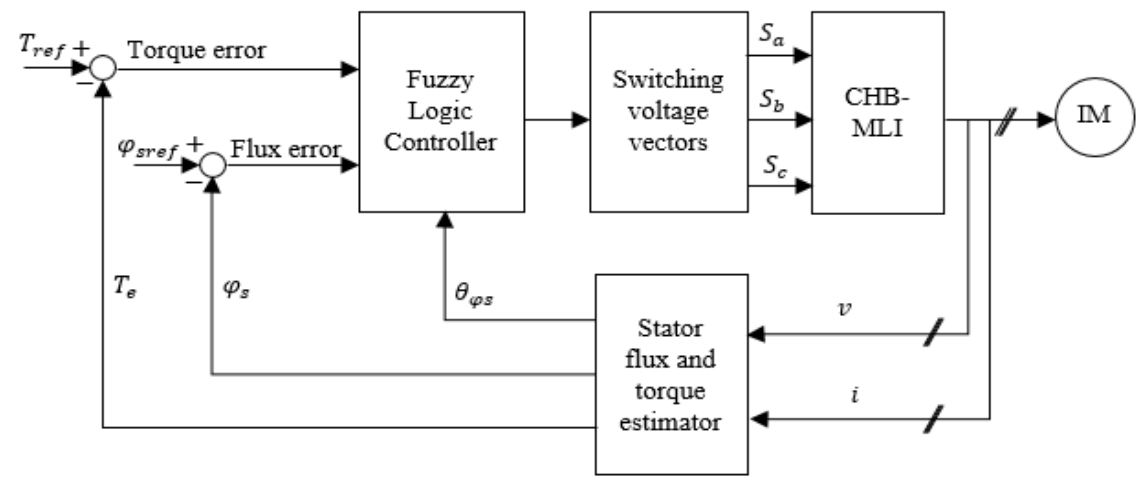

(a)
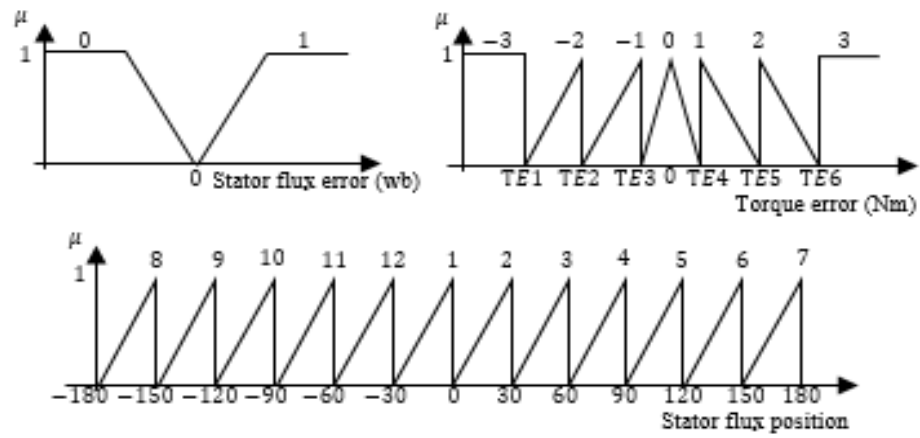

(b)

Figure 11. Structure of fuzzy logic controller by using CHB-DTC, (a) Fuzzy logic controller for CHB-DTC represented by block diagram and (b) Membership function of fuzzy logic controller [79]

\section{RESULTS AND DISCUSSION}

Overall, the improvement of DTC by using the variety topologies of MLI have been reviewed including the proposed strategy and method with the aim of achieve the good performance of DTC. Those approaches are available and relevant to be employed in the AC drive system according to the number of researches. Besides, the critical review of this paper is summarized in the Table 2 as the features discussed are look-up table, hysteresis comparator, space vector modulation, carrier frequency, duty cycle, voltage balancing, virtual vector, sensorless control and AI control. As compared to the two-level inverter, the complex implementation, extra cost and increase switching devices possessed by MLI are remunerated with the superior and excellent DTC performance. 
Table 2. The comparison features of DTC by using conventional and multilevel inverter

\begin{tabular}{|c|c|c|c|c|c|}
\hline Features & Terms & $\begin{array}{c}\text { Two-level } \\
\text { inverter DTC }\end{array}$ & Reference & $\begin{array}{l}\text { Multilevel inverter } \\
\text { DTC }\end{array}$ & Reference \\
\hline Look-up table & Size of voltage vectors & small & [1] & large & {$[17] /[18]$} \\
\hline $\begin{array}{l}\text { Hysteresis } \\
\text { comparator }\end{array}$ & $\begin{array}{l}\text { Number of levels of } \\
\text { Flux/Torque } \\
\text { Range of Hysteresis } \\
\text { bandwidth }\end{array}$ & $\begin{array}{l}\text { two/three } \\
\text { limited }\end{array}$ & [1] & $\begin{array}{c}\text { five/seven } \\
\text { multi }\end{array}$ & [41] \\
\hline $\begin{array}{l}\text { Space vector } \\
\text { modulation }\end{array}$ & $\begin{array}{l}\text { Number of triangular } \\
\text { fractals in one hexagonal } \\
\text { diagram } \\
\text { Time adjacent of nearest } \\
\text { voltage vector } \\
\text { Precision of voltage vector } \\
\text { projection }\end{array}$ & $\begin{array}{l}\text { long } \\
\text { low }\end{array}$ & [46] & $\begin{array}{c}64 \\
\text { short } \\
\text { high }\end{array}$ & [48] \\
\hline $\begin{array}{l}\text { Carrier } \\
\text { frequency }\end{array}$ & $\begin{array}{l}\text { Number of triangular } \\
\text { carrier frequency }\end{array}$ & two & {$[55]$} & $\operatorname{six}$ & [57] \\
\hline Duty cycle & $\begin{array}{l}\text { Number of voltage vectors } \\
\text { in one-time interval } \\
\text { switching }\end{array}$ & two & [59] & two/three & [4] \\
\hline $\begin{array}{l}\text { Voltage } \\
\text { balancing }\end{array}$ & $\begin{array}{l}\text { Number of voltage vector } \\
\text { caused the unbalanced }\end{array}$ & none & - & two & {$[65]$} \\
\hline Virtual vector & $\begin{array}{l}\text { Number of the merging } \\
\text { voltage vector }\end{array}$ & none & - & two & [33] \\
\hline $\begin{array}{l}\text { Sensorless } \\
\text { control }\end{array}$ & $\begin{array}{l}\text { Electrical and mechanical } \\
\text { equation model }\end{array}$ & unchanged & [70] & unchanged & [72] \\
\hline AI control such & Size of fuzzy rules & small & [78] & large & [79] \\
\hline as fuzzy and NN & Size of layers and neuron & small & [82] & large & [83] \\
\hline
\end{tabular}

\section{CONCLUSION}

In the adjustable speed drive applications, the DTC drive gains high interest due to its simple and robust attributes. Definitely, DTC requires some improvements to sustain its operation and overcome its weaknesses. One of the improvements is the application of MLI which acquires the extra voltage vectors for optimal selection on the inverter switching. Several features of DTC developments by using MLI have been critically reviewed thus the comparisons between conventional inverter and MLI are summarized. A lot of consideration needs to be emphasized on when designing the MLI in the DTC system. The extra voltage vector acquired by MLI become flexible and reliable in the wide range of power application. Therefore, this review paper delivers the alternative research to those concern in this field to become their future research.

\section{ACKNOWLEDGEMENTS}

The authors gratefully acknowledge the financial support provided by the Ministry of Higher Education, Malaysia, (MOHE) and Universiti Teknikal Malaysia Melaka (UTeM).

\section{REFERENCES}

[1] I. Takahashi and T. Noguchi, "A New Quick-Response and High-Efficiency Control Strategy of an Induction Motor," IEEE Trans. Ind. Appl., vol. IA-22, pp. 820-827, 1986.

[2] S. A. L. Ramahlingam, A. Jidin, T. Sutikno, and L. L. Raj, "3-level DTC of induction machine using constant switching frequency method by utilizing multiband carrier," Int J Pow Elec \& Dri Syst, vol. 7, pp. 638-647, 2016.

[3] D. Mohan, X. Zhang, and G. H. Beng Foo, "Generalized DTC Strategy for Multilevel Inverter Fed IPMSMs with Constant Inverter Switching Frequency and Reduced Torque Ripples," IEEE Trans. Energy Convers., vol. 32, pp. 1031-1041, 2017.

[4] D. Mohan, X. Zhang, and G. H. B. Foo, "A Simple Duty Cycle Control Strategy to Reduce Torque Ripples and Improve Low-Speed Performance of a Three-Level Inverter Fed DTC IPMSM Drive," IEEE Trans. Ind. Electron., vol. 64, pp. 2709-2721, 2017.

[5] A. Jidin, K. A. Karim, K. Rahim, L. Raj, Logan Victor, S. Ramahlingam, and T. Sutikno, "A Review on Constant Switching Frequency Techniques for Direct Torque Control of Induction Motor," Indones. J. Electr. Eng. Comput. Sci., vol. 7, pp. 364-372, 2017.

[6] S. Allirani, N. S. Lakshmi, and H. Vidhya, "Performance analysis on direct torque controlled induction motor drive with varying hysteresis controller bandwidth," Int J Pow Elec \& Dri Syst, vol. 11, pp. 1165-1174, 2020.

[7] A. N. Abdullah and M. H. Ali, "Direct torque control of IM using PID controller," Int. J. Electr. Comput. Eng., vol. 10, pp. 617-625, 2020.

[8] R. H. Kumar, A. Iqbal, and N. C. Lenin, "Review of recent advancements of direct torque control in induction motor drives - a decade of progress," IET Power Electron., vol. 11, pp. 1-15, 2018. 
[9] T. Sutikno, N. R. N. Idris, and A. Jidin, "A review of direct torque control of induction motors for sustainable reliability and energy efficient drives," Renew. Sustain. Energy Rev., vol. 32, pp. 548-558, 2014.

[10] C. Laoufi, Z. Sadoune, A. Abbou, and M. Akherraz, "New model of electric traction drive based sliding mode controller in field-oriented control of induction motor fed by multilevel inverter," Int J Pow Elec \& Dri Syst, vol. 11, pp. 242-250, 2020.

[11] D. Roy, S. Kumar, and M. Singh, "A novel region selection approach of SVPWM for a three-level NPC inverter used in electric vehicle," Int J Pow Elec \& Dri Syst, vol. 10, pp. 1705-1713, 2019.

[12] G. Shashibhushan and S. Sonoli, "Multi-objective solution with PSO algorithm for minimization of torque ripple and speed settling time by using solar-fed 11, 9 and 3-level multi-level inverter with vector control of induction motor," Int J Pow Elec \& Dri Syst, vol. 11, pp. 827-832, 2020.

[13] G. Shashibhushan and S. Sonoli, "Starting torque and torque ripple reduction using SVPWM based vector control of induction motor with nine-level cascaded multilevel Inverter fed with solar PV power," Int J Pow Elec \& Dri Syst, vol. 10, pp. 1123-1132, 2019.

[14] S. Kouro et al., "Recent Advances and Industrial Applications of Multilevel Converters," IEEE Trans. Ind. Electron., vol. 57, pp. 2553-2580, 2010.

[15] W. A. Halim, S. Ganeson, M. Azri, and T. N. A. T. Azam, "Review of Multilevel Inverter Topologies and Its Applications," J. Telecommun. Electron. Comput. Eng., vol. 8, pp. 51-56, 2016.

[16] N. Prabaharan and K. Palanisamy, "A comprehensive review on reduced switch multilevel inverter topologies , modulation techniques and applications," Renew. Sustain. Energy Rev., vol. 76, pp. 1248-1282, 2017.

[17] L. Ouboubker, M. Khafallah, J. Lamterkati, and K. Chikh, "Comparison between DTC using a two-level inverters and DTC using a three level inverters of Induction Motor," 2014.

[18] N. M. Nordin, N. R. N. Idris, and N. a. Azli, "Direct Torque Control with 5-level cascaded H-bridge multilevel inverter for induction machines," IECON 2011 - 37th Annu. Conf. IEEE Ind. Electron. Soc., pp. 4691-4697, 2011.

[19] S. Priya, A. Suresh, and M. R. Rashmi, "GCMT-249 Investigation and Performance Analysis of Direct Torque Control of 3phase Induction Motor using 7 Level Neutral Point Clamped Multilevel Inverter," Indian J. Sci. Technol., vol. 9, pp. 1-7, 2016.

[20] A. Rahmati, M. Arasteh, S. Farhangi, and A. Abrishamifar, "Flying capacitor DTC drive with reductions in common mode voltage and stator overvoltage," J. Power Electron., vol. 11, pp. 512-519, 2011.

[21] S. Mukherjee and G. Poddar, "Direct torque control of squirrel cage induction motor for optimum current ripple using three-level inverter," IET Power Electron., vol. 3, pp. 904-914, 2010.

[22] G. Brando, A. Dannier, A. Del Pizzo, R. Rizzo, and I. Spina, "Generalised look-up table concept for direct torque control in induction drives with multilevel inverters," Electr. Power Appl. IET, vol. 9, pp. 556-567, 2015.

[23] V. T. R. V.T.Somasekhar, KGopakumar, Andre Pittet, "A Novel PWM Inverter Switching Strategy for a Dual Two-level Inverter Fed Open - end Winding Induction Motor Drive," in IEEE PEDS, 2001, pp. 196-202.

[24] M. K. Rahim, A. Jidin, and T. Sutikno, "Enhanced torque control and reduced switching frequency in direct torque control utilizing optimal switching strategy for dual-inverter supplied drive," Int J Pow Elec \& Dri Syst, vol. 7, pp. 328-339, 2016.

[25] K. V. P. Kumar and T. V. Kumar, "Improvised Direct Torque Control Strategies of Open End Winding PMSM Fed With Multi-Level Inversion," in 2018 IEEE International Conference on Industrial Technology (ICIT), 2018, pp. 425-430.

[26] K. M. Ravi Eswar and T. Vinay Kumar, "An Improved Direct Torque Control of Three- Level Dual Inverter fed Open-Ended Winding Induction Motor Drive Based on Modified," IEEE Trans. Power Electron., pp. 1-10, 2019.

[27] S. Suresh, P. P. Rajeevan, and S. Member, "Virtual Space Vector Based Direct Torque Control Schemes for Induction Motor Drives," IEEE Trans. Ind. Appl., 2020.

[28] D. Casadei, A. Member, G. Serra, and A. Tani, "The Use of Matrix Converters in Direct Torque Control of Induction Machines," IEEE Trans. Ind. Electron., vol. 48, pp. 1057-1064, 2001.

[29] M. Deshpande, M. S. Kumaran, and R. Muthu, "Direct torque control of the direct three level matrix converter based on induction motor drive," Rev. Tec. la Fac. Ing. Univ. del Zulia, vol. 39, pp. 194-204, 2016.

[30] S. S. Sebtahmadi, H. Pirasteh, S. H. Aghay Kaboli, A. Radan, and S. Mekhilef, "A 12-Sector Space Vector Switching Scheme for Performance Improvement of Matrix-Converter-Based DTC of IM Drive," IEEE Trans. Power Electron., vol. 30, pp. 3804-3817, 2015.

[31] S. Li, Y. Yan, W. Chen, S. Ai, and C. Xia, "A Sub-Region Based Direct Torque Control Method of Matrix Converter Fed PMSM Drive System," in 2016 IEEE 25th International Symposium on Industrial Electronics (ISIE), 2016, pp. 128-133.

[32] S. Y. Kang, H. U. Shin, S. M. Park, and K. B. Lee, "Optimal Voltage Vector Selection Method for Torque Ripple Reduction in the Direct Torque Control of Five-phase Induction Motors," J. Power Electron., vol. 17, pp. 12031210, 2017.

[33] S. Payami and R. K. Behera, "An Improved DTC Technique for Low-Speed Operation of a Five-Phase Induction Motor," IEEE Trans. Ind. Electron., vol. 64, pp. 3513-3523, 2017.

[34] Y. N. Tatte and M. V Aware, "Direct Torque Control of Five-Phase Induction Motor with Common-Mode Voltage and Current Harmonics Reduction," IEEE Trans. Power Electron., vol. 8993, pp. 8644-8654, 2017.

[35] Y. N. Tatte and M. V Aware, "Torque Ripple and Harmonic Current Reduction in a Three-Level Inverter-Fed Direct-Torque- Controlled Five-Phase Induction Motor," IEEE Trans. Ind. Electron., vol. 64, pp. 5265-5275, 2017.

[36] J. K. Pandit, M. Aware, R. Nemade, and Y. Tatte, "Simplified Implementation of Synthetic Vectors for DTC of Asymmetric Six-Phase Induction Motor Drives," IEEE Trans. Ind. Appl., vol. 9994, pp. 1-13, 2018.

[37] S. Sharma, M. Aware, A. Bhowate, and E. Levi, "Performance improvement in six-phase symmetrical induction 
motor by using synthetic voltage vector based direct torque control," IET Electr. Power Appl., vol. 13, pp. 16381646, 2019.

[38] M. H. Holakooie, M. Ojaghi, and A. Taheri, "Direct Torque Control of Six-phase Induction Motor With a Novel MRAS-Based Stator Resistance Estimator," IEEE Trans. Ind. Electron., 2018.

[39] J. K. Pandit, M. V. Aware, R. Nemade, and E. Levi, "Direct Torque Control Scheme for a Six-Phase Induction Motor with Reduced Torque Ripple," IEEE Trans. Power Electron., vol. 32, pp. 1-1, 2017.

[40] L. Ouboubker, M. Khafallah, J. Lamterkati, and A. El, "High torque control performance utilizing a three level inverters with a simple switching strategy of induction machine," in 2nd International Conference on Electrical and Information Technologies, 2016, pp. 2-7.

[41] R. Nair, A. Jidin, M. N. Othman, M. H. Jopri, and M. Manap, "Comparison performance of 3-Level and 5-Level Cascaded H-Bridge multilevel inverter of DTC of Induction Machine,” 2013 Int. Conf. Electr. Mach. Syst. ICEMS 2013, pp. 2100-2104, 2013.

[42] N. F. Alias, A. Jidin, A. Razi, T. Sutikno, and H. Ismail, "Simple switching strategy for high-torque control performance utilizing Neutral Point Clamped multilevel inverter," Int J Pow Elec \& Dri Syst, vol. 3, pp. 400-408, 2013.

[43] F. Montazeri and D. A. Khaburi, "Torque Ripple Reduction in Direct Torque Control of Induction Machines by Use of all Voltage Vectors of Matrix Converters," in 1st Power Electronic \& Drive Systems \& Technologies Conference, 2010, pp. 261-266.

[44] N. R. N. Idris and A. M. Yatim, "Direct torque control of induction machines with constant switching frequency and reduced torque ripple," IEEE Trans. Ind. Electron., vol. 51, pp. 758-767, 2004.

[45] T. G. Habetler, F. Profumo, S. Member, M. Pastorelli, and L. M. Tolbert, "Direct Torque Control of Induction Machines using Space Vector Modulation," IEEE Trans. Ind. Appl., vol. 28, pp. 1045-1053, 1992.

[46] A. Ouarda and F. Ben Salem, "Induction machine DTC-SVM: A comparison between two approaches," 2013 10th Int. Multi-Conference Syst. Signals Devices, SSD 2013, pp. 1-7, 2013.

[47] N. Venkataramana Naik, A. Panda, and S. P. Singh, "A Three-Level Fuzzy-2 DTC of Induction Motor Drive Using SVPWM," IEEE Trans. Ind. Electron., vol. 63, pp. 1467-1479, 2016.

[48] M. A. Usta, H. I. Okumus, and H. Kahveci, "A simplified three-level SVM-DTC induction motor drive with speed and stator resistance estimation based on extended Kalman filter," Electr. Eng., vol. 99, pp. 707-720, 2017.

[49] A. Lewicki and M. Morawiec, "Space-vector pulsewidth modulation for a seven-level cascaded H-bridge inverter with the control of DC-link voltages," Bull. Polish Acad. Sci. Tech. Sci., vol. 65, pp. 619-628, 2017.

[50] B. R. Vinod, M. R. Baiju, and G. Shiny, "Five-Level Inverter-Fed Space Vector Based Direct Torque Control of Open-End Winding Induction Motor Drive," IEEE Trans. Energy Convers., vol. 33, pp. 1392-1401, 2018.

[51] B. R. Vinod, G. Shiny, and M. R. Baiju, "Space Vector Direct Torque Control for Five-level Open- end winding Induction Motor Drive to suppress Harmonic Spikes," IEEE Region 10 Symposium (TENSYMP), 2017, pp. 4-8.

[52] B. R. Vinod and G. Shiny, "Direct Torque Control Scheme for a Four-Level-Inverter Fed Open-End-Winding Induction Motor," IEEE Trans. Energy Convers., vol. 34, pp. 2209-2217, 2019.

[53] A. Badiee-Azandehi, A. Yousefi-Talouki, and M. Rezanejad, "Direct torque control space vector modulation of five-phase interior permanent magnet synchronous motor using matrix converter," Aust. J. Electr. Electron. Eng., vol. 12, pp. 113-124, 2015.

[54] J. Listwan and K. Pienkowski, "Experimental studies of DTC-SVM control of six-phase induction motor with application of the super-twisting sliding mode controllers," 2018 Int. Symp. Electr. Mach. SME 2018, pp. 1-6, 2018.

[55] N. R. N. Idris and A. H. M. Yatim, "Reduced torque ripple and constant torque switching frequency strategy for direct torque control of induction machine," in APEC 2000. Fifteenth Annual IEEE Applied Power Electronics Conference and Exposition, 2002, pp. 154-161.

[56] A. Jidin, N. R. N. Idris, A. H. M. Yatim, A. Z. Jidin, and T. Sutikno, "Torque ripple minimization in DTC induction motor drive using constant frequency torque controller," 2010 Int. Conf. Electr. Mach. Syst. ICEMS2010, pp. 919$924,2010$.

[57] N. M. Nordin, N. A. Azli, N. R. N. Idris, N. H. Ramlan, and T. Sutikno, "Constant frequency torque controller for DTC with multilevel inverter of induction machines," Int J Pow Elec \& Dri Syst, vol. 7, pp. 28-44, 2016.

[58] S. S. Hakami, I. M. Alsofyani, and K. B. Lee, "Torque Ripple Reduction and Flux-Droop Minimization of DTC with Improved Interleaving CSFTC of im Fed by Three-Level NPC Inverter," IEEE Access, vol. 7, pp. 184266$184275,2019$.

[59] J.-K. Kang and S.-K. Sul, "New direct torque control of induction motor for minimum torque ripple and constant switching frequency," IEEE Trans. Ind. Appl., vol. 35, pp. 1076-1082, 1999.

[60] G. Abad and J. Poza, "Two-Level VSC Based Predictive Direct Torque Control of the Doubly Fed Induction Machine With Reduced Torque and Flux Ripples at Low Constant Switching Frequency," IEEE Trans. Power Electron., vol. 23, pp. 1050-1061, 2008.

[61] Y. Zhang and J. Zhu, "A Novel Duty Cycle Control Strategy to Reduce Both Torque and Flux Ripples for DTC of Permanent Magnet Synchronous Motor Drives With Switching Frequency Reduction," IEEE Trans. Power Electron., vol. 26, pp. 3055-3067, 2011.

[62] W. Chen, C.-L. Xia, Y.-Y. Zhao, Y. Yan, and Z.-Q. Zhou, "Torque Ripple Reduction in Three-Level Inverter-Fed Permanent Magnet Synchronous Motor Drives by Duty-Cycle Direct Torque Control Using an Evaluation Table," J. Power Electron., vol. 17, pp. 368-379, 2017.

[63] Y. Ren, Z. Q. Zhu, J. E. Green, Y. Li, S. Zhu, and Z. Li, "Improved Duty-Ratio-Based Direct Torque Control for Dual Three-Phase Permanent Magnet Synchronous Machine Drives," IEEE Trans. Ind. Appl., vol. 55, pp. 5843- 
$5853,2019$.

[64] M. F. Escalante, J. C. Vannier, and A. Arzand, "Flying capacitor multilevel inverters and DTC motor drive applications," IEEE Trans. Ind. Electron., vol. 49, pp. 809-815, 2002.

[65] H. Ismail et al., "Direct Torque Control of Induction Machine Using 3- Level Neutral Point Clamped Inverter," 2015 IEEE Student Conf. Res. Dev., pp. 571-576, 2015.

[66] A. Sadeghi, M. Mohamadian, M. Shahparasti, and A. Fatemi, "A New Switching Algorithm for Voltage Balancing of a Three-Level NPC in DTC drive of a Three-Phase IM," Conf. Proc. - IEEE Appl. Power Electron. Conf. Expo. APEC, pp. 489-495, 2013.

[67] O. Sandre-Hernandez, J. Rangel-Magdaleno, R. Morales-Caporal, and E. Bonilla-Huerta, "HIL simulation of the DTC for a three-level inverter fed a PMSM with neutral-point balancing control based on FPGA," Electr. Eng., vol. 100, pp. 1441-1454, 2018.

[68] Z. Tan, Y. Li, and Y. Zeng, "A Three-Level Speed Sensor-less DTC Drive of Induction Motor Based on A FullOrder Flux Observer," 2002.

[69] H. C. L. Hou, Y. Li, X. Feng, "Improved Virtual Vector Direct Torque Control of Induction Motor Based on Threelevel NPC Inverter," 9th International Conference on Electronic Measurement \& Instruments, 2009, pp. 668-672.

[70] A. Monti, "A new state observer for sensorless DTC control," in 1998 Seventh International Conference on Power Electronics and Variable Speed Drives, 1998, pp. 311-317.

[71] I. M. Alsofyani and N. R. N. Idris, "Lookup-Table-Based DTC of Induction Machines with Improved Flux Regulation and Extended Kalman Filter State Estimator at Low-Speed Operation," IEEE Trans. Ind. Informatics, vol. 12 , pp. 1412-1425, 2016.

[72] M. A. Usta, H. I. Okumus, S. Guven, and E. S. Durak, "Speed Sensorless Direct Torque Control for Three-Level Diode-Clamped Inverter Fed Induction Motor Using Adaptive Flux Observer," 2015 9th Int. Conf. Electr. Electron. Eng., pp. 574-578, 2015.

[73] Y. Guo, X. Wang, Y. Guo, and W. Deng, "Speed-sensorless direct torque control scheme for matrix converter driven induction motor," J. Eng., vol. 2018, pp. 432-437, 2018.

[74] K. B. Lee and F. Blaabjerg, "Sensorless DTC-SVM for induction motor driven by a matrix converter using a parameter estimation strategy," IEEE Trans. Ind. Electron., vol. 55, pp. 512-521, 2008.

[75] B. S. Khaldi, H. Abu-Rub, A. Iqbal, R. Kennel, M. O. Mahmoudi, and D. Boukhetala, "Sensorless Direct Torque Control of Five-Phase Induction Motor Drives," in IECON 2011 - 37th Annual Conference of the IEEE Industrial Electronics Society, 2011, pp. 3501-3506.

[76] A. H. Almarhoon, Y. Ren, and Z. Q. Zhu, "Sensorless switching-table-based direct torque control for dual threephase PMSM drives," 2014 17th Int. Conf. Electr. Mach. Syst. ICEMS 2014, pp. 1616-1621, 2015.

[77] I. G. Bird and D. La Parra, "Fuzzy logic torque ripple reduction for DTC based AC Drives," Electron. Lett., vol. 33, pp. 1501-1502, 1997.

[78] H. Sudheer, S. F. Kodad, and B. Sarvesh, "Regular paper Improved Fuzzy Logic based DTC of Induction machine for wide range of speed control using AI based controllers," J. Electr. Syst., vol. 2, pp. 301-314, 2016.

[79] A. Mortezaei, N. A. Azli, N. R. N. Idris, S. Mahmoodi, and N. M. Nordin, "Direct torque control of induction machines utilizing 3-level cascaded H-Bridge Multilevel Inverter and fuzzy logic," 2011 IEEE Appl. Power Electron. Colloq., pp. 116-121, 2011.

[80] J. Lara, V. Guzman, J. Restrepo, M. . Gimenez, and A. Cabello, "Matrix Converter Induction Motor Drive with DTC-Based Fuzzy Control," 42 ${ }^{\text {nd }}$ International Universities Power Engineering Conference, 2007, pp. 1115-1121.

[81] D. Ahmed, B. Mokhtar, and B. Aek, "DTC hybrid by different techniques of observation with Artificial Neuronal Network (ANN) for induction machine drives," Int J Pow Elec \& Dri Syst, vol. 10, pp. 697-708, 2019.

[82] D. Ahmed, B. Mokhtar, and B. Aek, "DTC-ANN-2-level hybrid by neuronal hysteresis with mechanical sensorless induction motor drive using KUBOTA observer," Int J Pow Elec \& Dri Syst, vol. 11, pp. 34-44, 2020.

[83] P. Q. Dzung, "A New Artificial Neural Network - Direct Torque Control for Matrix Converter Fed Three-Phase Induction Motor," in 2005 International Conference on Power Electronics and Drives Systems, 2005, pp. 78-83.

[84] M. R. Douiri, M. Hbib, and M. Cherkaoui, "Neural computation based vector controlled asynchronous motor fed by three levels NPC," J. Energy Syst., vol. 8, pp. 693-707, 2017.

[85] S. K. Barik and K. K. Jaladi, "Five-Phase Induction Motor DTC-SVM Scheme with PI Controller and ANN Controller," J. Procedia Technol., vol. 25, pp. 816-823, 2016.

[86] H. Benbouhenni, "Five-Level DTC Based on ANN of IM Using 13-Level Hysteresis Control To Reduce Torque Ripple Comparing With Conventional Control," Int. J. Neural Networks Adv. Appl., vol. 2, pp. 33-39, 2018.

[87] K. B. Lee, S. H. Huh, J. Y. Yoo, and F. Blaabjerg, "Performance improvement of DTC for induction motor-fed by three-level inverter with an uncertainty observer using RBFN," IEEE Trans. Energy Convers., vol. 20, pp. 276-283, 2005.

[88] M. A. Usta, H. I. Okumus, H. Kahveci, and E. S. Durak, "Sensorless Feedback Linearization Direct Torque Control ( FBL-DTC ) for Induction Motor Drive with Five-Level Cascaded H-Bridge Inverter," 2018 IEEE 18th Int. Power Electron. Motion Control Conf., pp. 1025-1030, 2018.

[89] H. Echeikh, R. Trabelsi, H. Kesraoui, A. Iqbal, and M. F. Mimouni, "Torque ripples improvement of direct torque controlled five-phase induction motor drive using backstepping control," Int J Pow Elec \& Dri Syst, vol. 11, pp. $64-74,2020$. 


\section{BIOGRAPHIES OF AUTHORS}
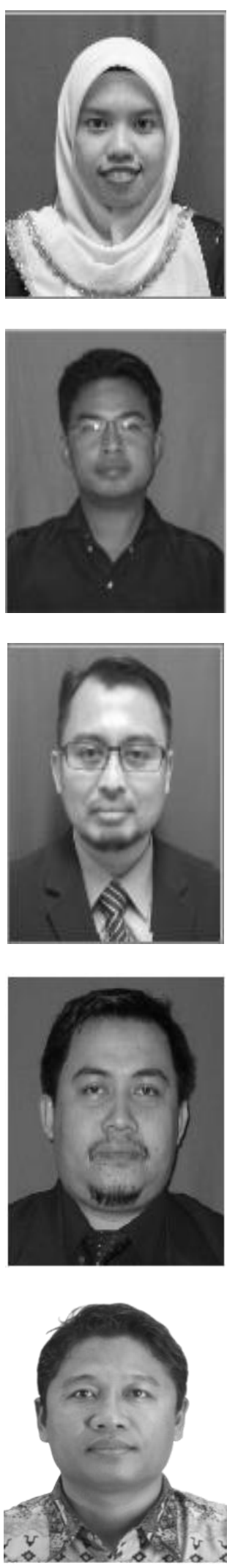

S. A. A. Tarusan received the B.Eng. degrees from Universiti Teknologi Malaysia, Johor Bahru, Malaysia, in 2008 and M.Eng. degrees from Universiti Malaya, Malaysia, in 2012. She is currently pursuing PhD under Power Electronics and Drives Research Group (PEDG) in the Faculty of Electrical Engineering, Universiti Teknikal Malaysia Melaka, Melaka, Malaysia. Her research interests include power electronics and motor drive systems.

A. Jidin received the B.Eng. degrees, M.Eng. degrees and Ph.D. degree in power electronics and drives from Universiti Teknologi Malaysia, Johor Bahru, Malaysia, in 2002, 2004 and 2011, respectively. He is currently an academician in Faculty of Electrical Engineering, Universiti Teknikal Malaysia Melaka, Melaka, Malaysia. He is also an active researcher in Power Electronics and Drives Research Group (PEDG) that established under the same faculty. His research interests include power electronics, motor drive systems, field-programmable gate array, and DSP applications.

M. L. M. Jamil received B.Eng. degree from the Universiti Teknologi MARA, Shah Alam, Malaysia, in 2000, M.Sc. degree from University of Newcastle upon Tyne, U.K., in 2003, and Ph.D. degree from The University of Sheffield, Sheffield, U.K., in 2011, all in electrical engineering. $\mathrm{He}$ is currently an academician in Faculty of Electrical Engineering, University Teknikal Malaysia Melaka, Melaka, Malaysia. He is also an active researcher in Power Electronics and Drives Research Group (PEDG) that established under the same faculty. His research interests include the design, control and analysis of permanent-magnet machines.

K. A. Karim received the M.Sc. from University of Bradford and Ph.D. degrees from the University of Nottingham, UK, in 2003 and 2011, respectively $\mathrm{He}$ is currently an academician in Faculty of Electrical Engineering, University Teknikal Malaysia Melaka, Melaka, Malaysia. He is also an active researcher in Power Electronics and Drives Research Group (PEDG) that established under the same faculty. His research interests include electrical machine design, power electronics, and electric vehicle.

Tole Sutikno is a Lecturer in Electrical Engineering Department at the Universitad Ahmad Dahlan (UAD), Yogyakarta, Indonesia. He received his B.Eng., M.Eng. and Ph.D. degree in Electrical Engineering from Universitas Diponegoro (Semarang, Indonesia), Universitas Gadjah Mada (Yogyakarta, Indonesia) and Universiti Teknologi Malaysia (Johor, Malaysia), in 1999, 2004 and 2016, respectively. He has been an Associate Professor in UAD, Yogyakarta, Indonesia since 2008. He is currently an Editor-in-Chief of the TELKOMNIKA, Director of LPPI UAD, and the Head of the Embedded Systems and Power Electronics Research Group. His research interests include the field of digital design, industrial electronics, industrial informatics, power electronics, motor drives, industrial applications, FPGA applications, artificial intelligence, intelligent control, embedded system and digital library. 